\title{
ANTASENA BIOHIDROGEN: GENERATOR BERBASIS LIMBAH KELAPA SAWIT GUNA MENINGKATKAN KERJA SAMA INDONESIA-TIONGKOK DI BIDANG RENEWABLE ENERGY
}

\author{
Ibrahim Fathahillah Hizbul Islam, Risa Wahyu Widyastuti, Adzon Nugraha Rizky \\ Pratama, Agung Purniawan* \\ Institut Teknologi Sepuluh Nopember \\ ibrahim.task2@gmail.com \\ risawahyu4@gmail.com \\ adzonnrp@gmail.com \\ agung_pur@mat-eng.its.ac.id*
}

\begin{abstract}
ABSTRAK
Minat energi di Indonesia terus meningkat setiap tahun dan diperkirakan mencapai $23 \%$ pada tahun 2050. Indonesia memiliki hubungan perdagangan erat dengan Tiongkok khususnya dalam bidang ekspor komoditi unggulan berupa kelapa sawit yang mampu dihasilkan Indonesia sebanyak 48 juta ton/tahun dan menjadi penghasil kelapa sawit terbanyak di dunia. Potensi biomassa dari limbah kelapa sawit seperti Palm Oil Mill Effluent (POME) dihasilkan sebanyak 50\% dari sisa ekstrak sebuah kelapa sawit yang mampu menghasilkan hidrogen dan pembangkit listrik hingga 10.000 Watt. Pretreatment pada POME dilakukan untuk menghilangkan bakteri metanasi. Hasilnya digunakan sebagai substrat untuk hidrolisis menggunakan $1 \mathrm{M} \mathrm{NaOH}$ pada temperatur $80^{\circ} \mathrm{C}$. Alat dan bahan yang diperlukan dalam pembuatan Antasena Biohidrogen adalah gas storage, pipa, POME, bioreaktor, dan filter. Dengan menggunakan strategi meta-pemeriksaan, penelitian diselesaikan dengan meninjau jurnal ilmiah dan simulasi menggunakan Solidworks untuk menentukan kesehatan generator, kerangka filtrasi, kekuatan material, dan perubahan tahap dalam gas. Dengan menggunakan bahan POME 18L, Antasena Biohidrogen dapat menghasilkan 10,8L H2/jam. Kemudian diubah menjadi listrik dengan perbandingan 0,699L biohidrogen untuk menghasilkan listrik sebesar $1000 \mathrm{~W} / \mathrm{h}$ dan diperkirakan mencapai 137.603,43 kWh/tahun. Dari hasil simulasi didapatkan faktor keamanan sebesar 2,4 sehingga aman untuk digunakan. Antasena Biohidrogen dapat menjadi investasi dengan BEP dalam waktu 1 tahun 26 hari, sehingga dapat disimpulkan efektif sebagai energi listrik terbarukan.
\end{abstract}

Kata Kunci: Bakteri, Biohidrogen, EBT, Generator, POME.

Received 8 July 2021 Accepted 31 January 2022

\section{PENDAHULUAN}

Konsumsi energi yang dibutuhkan masyarakat semakin meningkat. Pemerintah memperkirakan kebutuhan energi mencapai $23 \%$ pada tahun 2050 dan menargetkan optimalisasi penggunaan Energi Baru Terbarukan (EBT) mencapai 29\% [1]. Saat ini, banyak sumber daya terbarukan yang dikembangkan untuk menggantikan energi fosil dengan mengembangkan sumber energi terbarukan berupa biomassa. Laporan dari United State Department of Agriculture 2019, Indonesia adalah penghasil minyak sawit terbesar di planet ini, menghasilkan 42,50 per juta metrik muatan besar minyak kelapa sawit dan berkontribusi $58 \%$ dari produksi minyak sawit dunia [2]. Industri kelapa sawit menghasilkan waste yang disebut Palm Oil Mill Effluent (POME) yang menimbulkan masalah alam natural. POME kaya akan kandungan bahan organik dan dapat dengan mudah 
diuraikan oleh mikroorganisme [3]. POME dihasilkan sebanyak 50\% dari sisa ekstrak sebuah kelapa sawit yang berpotensi menghasilkan hidrogen dan pembangkit listrik hingga 10.000 Watt.

Berdasarkan data yang diberikan BPS 2014 menunjukkan Indonesia memiliki hubungan perdagangan erat dengan Tiongkok di bidang ekspor kelapa sawit. Potensi kerja sama ini akan semakin kuat dengan pernyataan Wakil Presiden FAW Group Coorporation yang ingin memajukan teknologi hidrogen dan berkolaborasi dengan mitra yang saling menguntungkan sesuai prinsip pelestarian lingkungan global. Fuel Cell $R \& D$ (FCRD) PT Toyota juga menyatakan dukungannya untuk Fuel Cell Electric Vehicle (FCEV) dalam menciptakan mobilitas masyarakat berbasis hidrogen di China, dan mengembangkan FCEV yang berkontribusi memecahkan masalah lingkungan termasuk mengurangi emisi CO2 serta polusi udara [4].

Dengan potensi aset minyak sawit yang berlimpah dan fokus energi baru yang ramah lingkungan yang harus dicapai di masa industri 4.0, inovasi diberikan kepada peralatan bio-reaktor yang menghasilkan biohidrogen dari limbah POME. Inovasi ini diharapkan mampu mewujudkan SDGs, khususnya pada poin 7 (Energi Bersih dan Terjangkau), poin 9 (Infrastruktur, Industri, dan Inovasi), dan poin 13 (Penanganan Perubahan Iklim), serta mengoptimalisasikan kerja sama Indonesia-Tiongkok dalam sektor teknologi dan lingkungan. Tujuan dalam penelitian ini untuk mengolah limbah Palm Oil Mill Effluent (POME) menjadi energi terbarukan berupa biohidrogen yang memiliki nilai ekonomi. Hal ini juga dapat memberikan kontribusi Antasena Biohidrogen dalam pembangunan berkelanjutan (Sustainable Development Goals). Dengan demikian, atas permasalahan dan tujuan penelitian tersebut penulis akan menganalisis mengenai antasena biohidrogen: generator berbasis limbah kelapa sawit guna meningkatkan kerja sama indonesia-tiongkok di bidang renewable energy.

\section{TINJAUAN PUSTAKA}

\section{Limbah Kelapa Sawit}

Limbah pengolahan kelapa sawit terdiri limbah padat dan limbah cair yang belum diketahui cara mengolahnya namun mempunyai kandungan yang sangat bermanfaat. Limbah padat, khususnya minyak kelapa sawit kosong, cangkang, serat, dan limbah cair POME [5]. POME merupakan limbah terbesar yang dihasilkan dari ukuran produksi kelapa sawit dan sampai sekarang olahan dari limbah POME belum maksimal untuk dimanfaatkan. POME memiliki sentralisasi COD dan BOD $96.300 \mathrm{mg} / \mathrm{L}$ dan $53.200 \mathrm{mg} / \mathrm{L}$ secara terpisah, sehingga cenderung dimanfaatkan sebagai substrat dalam menghantarkan biohidrogen [6].

\section{Bioreaktor}

Bioreaktor atau fermentator adalah tempat perubahan zat terjadi karena respons dalam tangki reaktor yang dibantu oleh mikroorganisme dalam iklim yang terkendali. Bioreaktor dapat digunakan untuk menghasilkan biometana dan biohidrogen [7]. Desain reaktor penghasil biohidrogen dapat dilihat pada gambar 1 . 


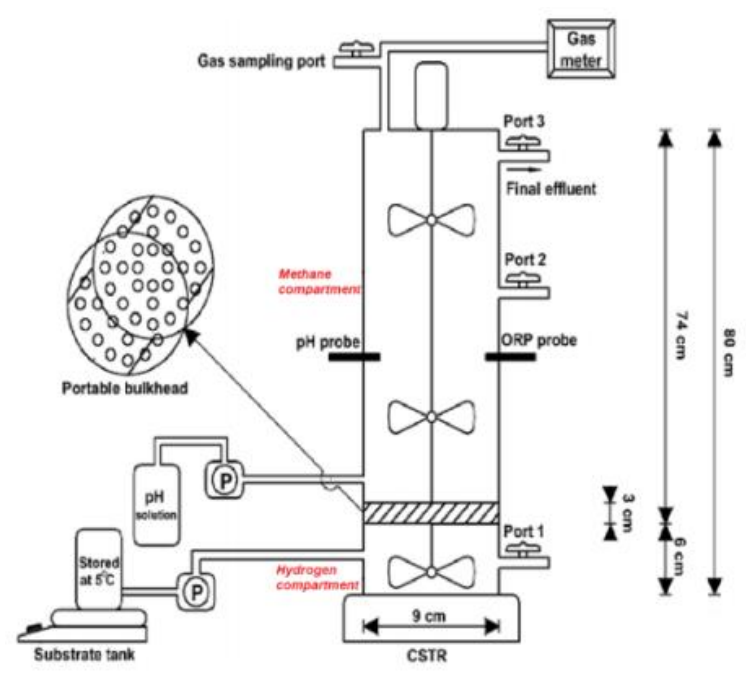

Gambar 1. Desain Bioreaktor Biohidrogen [8]

\section{Bakteri}

Dalam pembuatan biohidrogen dengan memanfaatkan organisme mikroskopis untuk siklus fermentasi, mikroba yang digunakan adalah Clostridium thermocellum, methanobacterium sp dan sytrophomonas sp [9]. Clostridium thermocellum adalah bakteri anaerob termofilik dengan kemampuan memproduksi hidrogen yang efisien mencapai $140 \mathrm{mmol} / \mathrm{L}$ pada ph antara 6 sampai 7 dengan suhu $60^{\circ} \mathrm{C}[10]$.

\section{Biohidrogen}

Biohidrogen adalah hidrogen yang dihasilkan oleh siklus alami dari bahan yang berkelanjutan, seperti biomassa, pemborosan biomassa, limbah pertanian, limbah modern, dan lain-lain [11]. Penciptaan hidrogen dari seumber limbah dengan proses fermentasi adalah teknik yang sangat menguntungkan di antara langkah-langkah pembuatan hidrogen elektif. Sehubungan dengan Sustainable Development Goals (SDGs) limbah, pembuatan hidrogen alami, yang dikenal sebagai "Green innovation" sedang mendapat perhatian yang signifikan sekarang ini karena membutuhkan sedikit energi dan dapat digabungkan dengan langkah-langkah olahan limbah cair. Hidrogen tidak beraroma, tiada berasa, tiada bewarna, dan tidak mengandung racun bila dimanfaatkan sebagai energi terbarukan tidak menghasilkan emisi gas buang namun memberikan air sebagai emisi yang aman. Jika dibandingkan dengan sumber daya fosil, hidrogen menghasilkan $122 \mathrm{~kJ} / \mathrm{g}$ energi, yang 2,75 kali lebih banyak daripada energi hidrokarbon [12].

\section{Generator (Fuel Cell)}

Fuel cell adalah perangkat daya transformasi energi yang mengubah hidrogen menjadi daya secara langsung melalui respons elektrokimia. Bagian dasar dari komponen energi adalah anoda, elektrolit, dan katoda. Perangkat listrik berkaitan dengan pedoman penyalaan listrik zat, fuel cell akan memberikan energi listrik [13].Komponen fuel cell terbuat dari elektrolit yang mengisolasi katoda dari anoda, elektrolit mengarahkan partikel, sedangkan elektron tidak dapat melompati elektrolit, kemudian elektrolit ini bukan merupakan pemancar daya dan selanjutnya menghindari reaksi kimia. Pada anoda secara efektif akan mengalirkan hidrogen dan pada katoda mengalirkan oksigen, aliran ini selesai secara terpisah. Karena dampak katalisator pada katoda, atom-atom gas akan berubah menjadi partikel. Respon di anoda memproduksi elektron bebas, sedangkan di katoda elektron bebas akan terikat [14]. Elektron bebas yang telah terjadi reaksi harus dibuang 
melalui saluran menuju anoda, sehingga dapat terjadi interaksi kimiawi-listrik dapat terjadi. Kalor yang muncul dari efek samping dari respons zat harus terus-menerus dihilangkan, sehingga energi listrik dapat dibentuk secara ekonomis. Skema kerja fuel cell daya dapat dilihat pada Gambar 2.

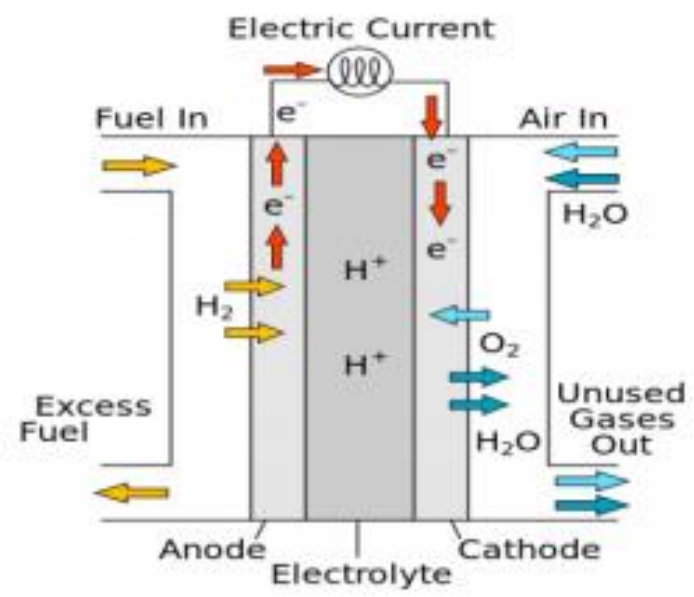

Gambar 2. Skema Fuel Cell [14]

\section{Kerja Sama Indonesia-Tiongkok}

Indonesia memiliki hubungan perdagangan erat dengan Tiongkok di bidang ekspor kelapa sawit. Menteri Luar Negeri, Retno Marsudi menyatakan bahwa saat ini Tiongkok telah mengembangkan biodiesel kelas 5 yang memerlukan palm oil sebagai bahan bakarnya, sehingga kebutuhan CPO Tiongkok akan naik. Presiden Jokowi telah menunjukkan kesiapan Indonesia untuk membangun kerja sama barang-barang tersebut dalam pertemuan dua sisi dengan Presiden China Xi Jinpinng [15].

Dalam bidang teknologi, Wakil Presiden FAW Group Coorporation berambisi untuk menciptakan mobilitas masyarakat berbasis hidrogen di China dengan alternatif pegembangan Fuel Cell Electric Vehicle (FCEV), sehingga dapat mengurangi emisi CO2. Ini adalah kesempatan luar biasa untuk Indonesia sebagai penghasil minyak kelapa sawit terbanyak di dunia dan peningkatan kemajuan mekanik di bidang hidrogen, sehingga Indonesia dapat menjadi pemasok inovasi biohidrohen berbasis fuel cell dari limbah cair kelapa sawit. Tentunya hal ini akan menguntungkan bagi China untuk memenuhi kebutuhan teknologi dan hidrogen, serta Indonesia untuk mengolah limbah kelapa sawit cair sehingga memiliki nilai ekonomi.

\section{METODE PENELITIAN}

Penelitian ini menggunakan berbagai sumebr refrensi jurnal untuk pengembangan konsep dalam rumusan masalah terangkat. Penelitian ini menggunakan metode meta analisis, dimana metode survei dilakukan terhadap beberapa literatur ilmiah. Dilakukan juga metode perancangan desain dan simulasi dengan software SolidWorks, Sketh-up dan Lumions guna mengetahui ketahanan material yang digunakan pada penelitian ini. Demikian pula, author meriset studi penulisan untuk menemukan sumber data dan sumber informasi dari berbagai jurnal dan media yang valid serta dapat dipercaya. Informasi yang dicari difokuskan pada permasalahan limbah POME yang belum diproses secara baik dan optimal di perusahaan, selain itu juga meninjau kebutuhan teknologi kedepan terhadap renewable energy. Tinjauan kerja sama yang ingin dicapai dengan Tiongkok. Adapun tahapan-tahapan tersebut sebaagi dapat dilihat gambar 3. 


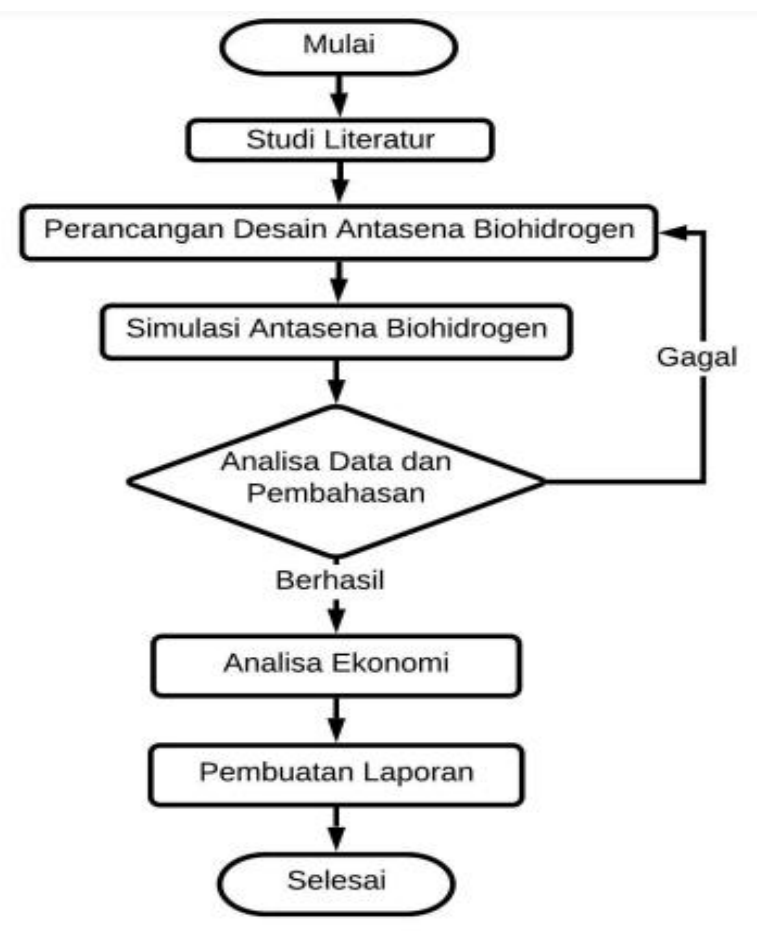

Gambar 3. Diagram Alur Penelitian

Pada penelitian ini juga penulis menggunakan perancangan desain bioreaktor penghasil biohidrogen, perancangan desain dilakukan menggunakan software Sketchup untuk menggambarkan bentuk visual dari Antasena Bohidrogen, serta software Lumion untuk mengetahui detail 3D dari rancangan yang telah dibuat. Pada tahap pemeriksaan informasi dan hipotesis yang digunakan didalam penulisan, dirinci dalam tahap ini. Keduanya akan dipersiapkan dan dihubungkan dengan isu yang diangkat dengan tujuan agar hubungan antara keduanya jelas dan ditemukan pengaturan elektif. Tujuan utama dalam tahap ini adalah untuk mencapai tujuan yang telah digambarkan dengan kesesuaian hasil simulasi yang didapat.

Kemudian, dalam tahap analisa matematis digunakan untuk mengetahui input yang dibutuhkan dalam pembuatan biohidrogen, yaitu kebutuhan bahan baku (POME) yang akan digunakan dan menghitung output berupa biohidrogen yang dihasilkan dalam waktu setahun. Penulis juga melakukan analisa ekonomi sesuai Break Event Point (BEP) sehingga dapat diketahui jumlah biaya/modal yang dibutuhkan/Capital Expenditure (CAPEX), serta Biaya operasional / Operating Expenditure (OPEX), dan dapat memperhitungkan waktu yang dibutuhkan untuk modal kembali. Setelah melakukan seluruh tahap di atas, dilakukan penarikan kesimpulan. Tahapan ini mempunyai tujuan menyimpulkan seluruh paper yang total dan lengkap.

\section{HASIL DAN PEMBAHASAN}

\section{Potensi Pengaplikasian Antasena Biohidrogen}

Bioreaktor penghasil Antasena Biohidrogen ini merupakan satu komponen alat yang bisa diaplikasikan pada suatu perusahaan yang ingin menghasilkan hidrogen secara langsung. Potensi terbesar diimplementasikan pada perusahaan minyak kelapa sawit yang belum memiliki alternatif pengolahan limbah berupa POME, sehingga dapat mengekspansi bisnis ke ranah produksi hidrogen yang berkelanjutan. Selain itu, perusahaan yang ingin merambah pada bisnis hidrogen juga dapat mengimplementasikan alat ini sebagai nilai tambah. Berdasarkan studi literatur yang telah dilakukan, instrument ini juga dapat 
digunakan dalam institusi pemerintah yaitu Kementrian Energi Sumber Daya Mineral (ESDM) sebagai upaya optimalisasi renewable energy, dimana pemerintah menargetkan penggunaannya mencapai $29 \%$ pada tahun 2050 [16].

Selain itu, adanya kerja sama yang telah terjalin dengan beberapa negara terkait ekspor kelapa sawit juga menjadi peluang besar untuk menawarkan alat bioreaktor penghasil Antasena Biohidrogen sebagai pengolah limbah POME yang dihasilkan. Kebutuhan negara lain seperti China terhadap hidrogen juga menjadi sasaran yang tepat untuk pengaplikasian alat ini.

\section{Kebutuhan Hidrogen sebagai Renewable Energy}

Peningkatan yang sangat besar untuk ketenagalistrikan saat ini diliputi oleh minyak, batu bara dan gas, di mana pemanfaatannya setiap tahun mencapai ekspansi 0,52\% untuk minyak, $13,70 \%$ untuk batu bara, dan $1,81 \%$ untuk gas. Jadi ekspansi lengkap dalam aset energi mencapai 16,01\% [17]. Energi yang dikelola dari Indonesia untuk subsidi adalah paling banyak subsidi ke daerah, dimana sumber energi sekarang ini yaitu energi fosil yaitu batubara dan minyak bumi yang dibiayai dengan 91,18 triliun rupiah dari pemerintah negara Indonesia ke daerah. Dengan tujuan agar kondisi energi saat ini dimana kebutuhan energi belum optimal, antara lain untuk keperluan industri, keluarga, transportasi dan bisnis. Sementara itu, pemerintah Indonesia mengharapkan untuk meningkatkan penggunaan Energi Baru Terbarukan atau EBT menjadi 29\% di tahun 2050 dapat diliat pada gambar 4.

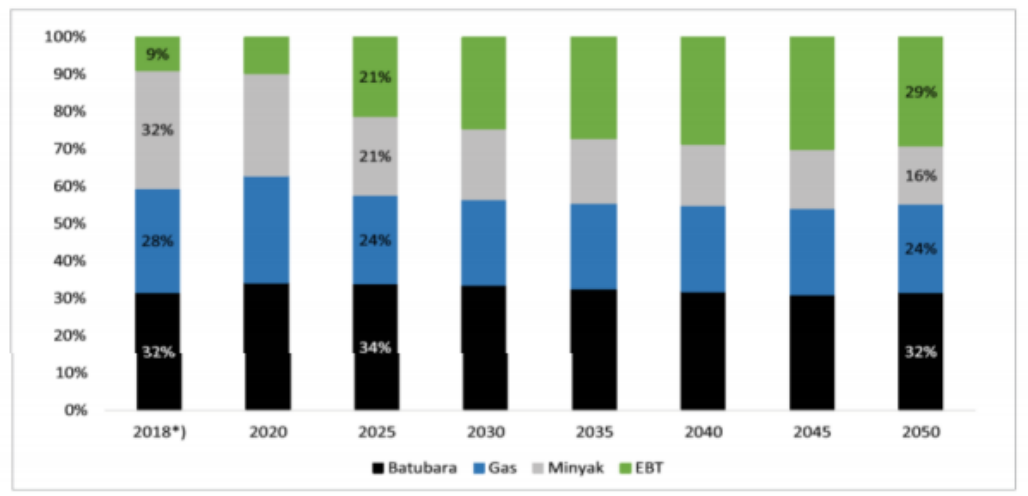

Gambar 4. Peningkatan Penggunaan EBT [16]

Dewasa ini, energi hidrogen di Indonesia dapat diperoleh dari gas alam yang mudah terbakar yang dikirim oleh 4 perusahaan gas besar. Biaya bisnisnya sebagai energi gas mencapai Rp200.000 sampai Rp1.700.000 untuk setiap 6000L (1 silinder) tergantung dengan kemurnian hidrogen. Sehingga daya fungsional fuel cell per kWh adalah Rp3300 sampai Rp28.300 dengan mempunyai asumsi bahwa per-kWh membutuhkan normal 0,8 sampai $1 \mathrm{~L}$ gas hidrogen. Karena gas hidrogen masih dijual sebagai energi gas benar-benar terasa mahal untuk dipergunakan masyarakat untuk kegiatan harian. Jika dipergunakan sebagai bahan bakar, maka penjualan atau komersialisasi dapat ditetapkan secara finansial.

Berkaitan dengan kebutuhan masyarakat terhadap energi listrik, dengan memanfaatkan sumber terbarukan dan dapat diolah kembali yang ada di setiap daerah yang belum terjangkau pembangkit listrik, melalui teknologi Antasena Biohidrogen yang dikembangkan dalam riset ini diperkirakan mampu memenuhi kebutuhan tersebut. 


\section{Analisa Desain Bioreaktor Penghasil Biohidrogen}

Tahap ini penulis membuat perancangan dan desain yang dibantu dengan software Solidworks, dan Sketchup untuk menggambarkan bentuk visual Antasena Bohidrogen. Perancangan desain juga dilakukan dengan software Lumion untuk mengetahui detail 3D dari rancangan yang telah dibuat. Rancangan tersebut dapat dilihat pada gambar 5 .

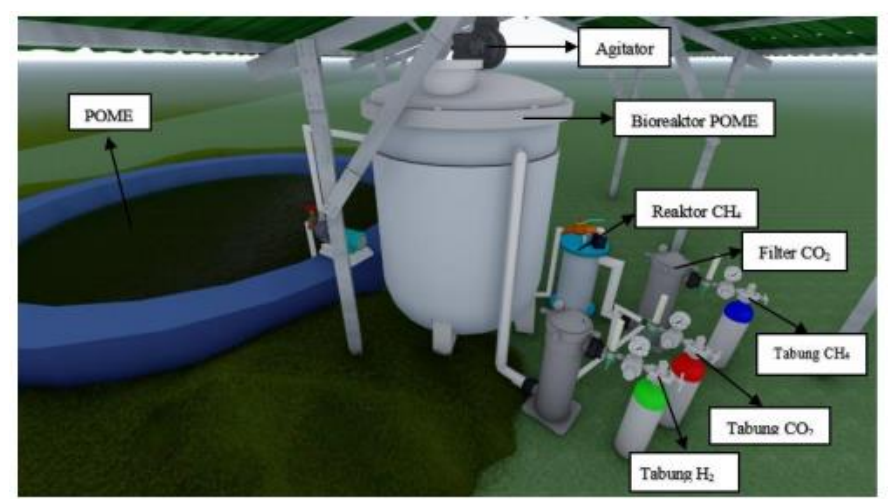

Gambar 5. Rancangan 3D Antasena Biohidrogen

Setelah pembuatan desain 3D, dilakukan simulasi desain alat bioreaktor dengan menggunakan software Solidworks Simulation untuk mengetahui kekuatan alat terhadap tekanan dan suhu.

\section{Hasil Simulasi Bioreaktor Antasena Biohidrogen}

Pemilihan material bioreaktor Antasena Biohidrogen mengutamakan ketahanan material terhadap tekanan tinggi dan suhu rendah. Material yang dipilih adalah stainless steel karena sifatnya yang tahan terhadap korosi, tahan panas, serta tidak bereaksi dengan bahan dalam bioreaktor. Pengujian simulasi dilakukan dengan konsep tekanan internal dan suhu tinggi menggunakan pengujian standar pada jurnal dan SNI 1452:2011 [18]. Dari desain yang telah dibuat dan telah diuji dengan tekanan 1 bar dan temperatur $60^{\circ} \mathrm{C}$ diperoleh nilai safety factor sebesar 2,4. Adapun data dapat dilihat pada gambar 6 dan nilai safety factor dapat dihitung dengan rumus seperti dibawah ini:

$$
\begin{aligned}
& S f=\frac{\text { yield strenght }}{\text { von mises }} \\
& S f=\frac{2,068 \times 10^{8} \mathrm{MPa}}{8,659 \times 10^{7} \mathrm{MPa}}=2,388 \approx 2,4
\end{aligned}
$$




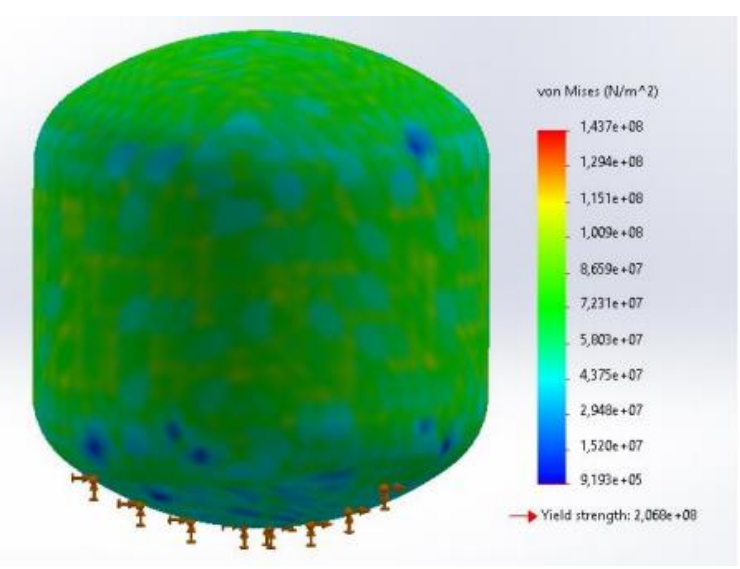

Gambar 6. Hasil Simulasi Pengujian Bioreaktor

Sumber: Penulis

\section{Alir Kerja Alat Antasena Biohidrogen}

Antasena Biohidrogen adalah teknologi penghasil energi hidrogen dengan memanfaatkan limbah POME. Enegi hidrogen yang telah didapat kemudian dikonversi menjadi listrik menggunakan fuel cell. Alat ini bekerja dengan cara memfermentasi limbah POME menjadi biohidrogen dengan penambahan bakteri clostridium thermocellum, methanobacterium $s p$ dan sytrophomonas $s p$ melalui proses dark fermentation pada bioreaktor. Substrat limbah yang mengandung asam asetat dan asam butirat hasil proses produksi biohidrogen akan digunakan kembali pada bioreaktor untuk mendapatkan gas metana yang dapat dimanfaatkan menjadi biogas. Alir kerja Antasena Biohidrogen dapat dilihat pada gambar 7 .

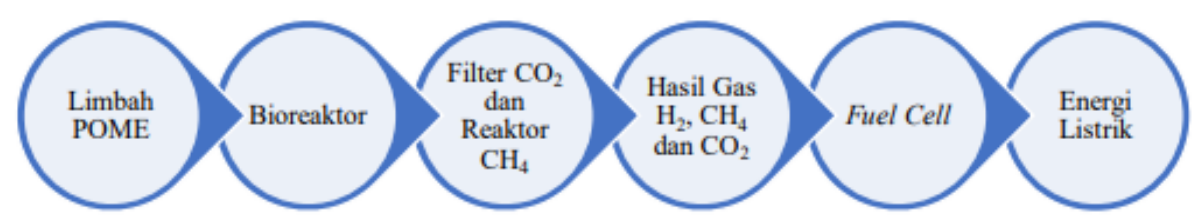

Gambar 7. Alir Kerja Antasena Biohidrogen Sumber: Penulis

Pada proses fermentasi limbah POME, dilakukan pre-treatment kimiawi menggunakan $\mathrm{NaOH} 10 \%$ yang dipanaskan pada temperatur $80^{\circ} \mathrm{C}$ selama 1 jam. Hal ini bertujuan untuk mengurangi bakteri agar mendapatkan jumlah hidrogen maksimal. Kemudian dilakukan proses hidrolisis untuk mengubah karbohidrat menjadi biohidrogen pada proses asidifikasi. Adapun reaksi yang terbentuk adalah sebagai berikut:

$$
\left(\mathrm{CH}_{6} \mathrm{H}_{10} \mathrm{O}_{5}\right) \rightarrow \mathrm{H}_{2}+\mathrm{CO}_{2}+\mathrm{H}_{2} \mathrm{~S}+\mathrm{C}_{2} \mathrm{H}_{4} \mathrm{O}_{2}+\mathrm{C}_{4} \mathrm{H}_{8} \mathrm{O}_{2}
$$

Reaksi tersebut terjadi dalam bioreaktor dengan suhu $60^{\circ} \mathrm{C}$ dan $\mathrm{pH} 5,5$ selama 2 hari. Setelah proses reaksi berlangsung akan dihasilkan gas dari bioreaktor sebesar $61 \% \mathrm{H}_{2}$, 85 ppm $\mathrm{H}_{2} \mathrm{~S}$, gas $\mathrm{CO}_{2}$ dan sisa subtrat yang akan diproses menjadi biogas. $\mathrm{Gas}_{2} \mathrm{H}_{2}$ yang didapatkan dari proses pertama kemudian dilakukan permurnian untuk menghilangkan sulfur dengan biodesulfurisasi menggunakan tekanan 1 atm dengan bakteri Thioalkalivibrio dan Thioalkalimicrobium [19]. Kemudian dilakukan filtrasi $\mathrm{CO}_{2}$ menggunakan tabung filtrasi. Filtrasi dilakukan untuk mendapatkan kadar hidrogen 99\%. Filtrasi ini menggunakan adsorben yang terbuat dari zeolit alam dan low-density polyethylene 
kemudian dicetak menggunakan mesin 3D printing [20]. Filter berbahan zeolit dipilih sebagai adsorben karena memiliki daya adsorpsi $\mathrm{CO}_{2}$ yang baik [21]. Setelah didapatkan hidrogen dengan kemurnian 99\% kemudian diolah menjadi listrik dengan fuel cell yang akan disalurkan untuk masyarakat.

\section{Analisa Matematis Alat Antasena Biohidrogen}

Fermentasi dilakukan dengan jenis fermentasi anaerobik pada lingkungan termofilik dengan suhu $60^{\circ} \mathrm{C}$ dan $\mathrm{pH} 5,5$. Biohidrogen yang dihasilkan yaitu $61 \%$. Dengan kapasitas 18L, maka perhitungan bahan yang dibutuhkan dirincikan sebagai berikut:

$61 \%=\frac{\text { Hasil Biohidrogen }}{18 L}$

$\frac{61}{100}=\frac{\text { Hasil Biohidrogen }}{18 L}$

$\frac{61}{100}=\frac{\text { Hasil Biohidrogen }}{18 L}$

Hasil Biohidrogen $=\frac{61 \times 18 L}{100}$

Hasil Biohidrogen $=10,98 \mathrm{~L}$

Sehingga, asumsi gas hidrogen yang diperoleh selama 1 tahun yaitu:

$10,98 \mathrm{~L}$ x $8760 \mathrm{jam}=96.184,8$ liter

Sedangkan kebutuhan POME dalam 1 tahun yaitu:

$18 \times 8760=157.680$ liter

Massa $=157.680 \times$ massa jenis POME

Massa $=157.680 \times 0,908=143.174,44 \mathrm{Kg}$

\section{Analisa Ekonomi Biohidrogen yang Dihasilkan}

Analisa ekonomi dilakukan dengan asumsi sebagai berikut:

1. Sistem beroperasi pada kondisi optimal selama 1 tahun penuh, 365 hari, 8760 jam operasi per tahun.

2. Reaktor dapat menghasilkan 10,98 liter gas hidrogen murni per jam.

3. Setiap fuel cell dapat menghasilkan listrik 1000Wh dengan konsumsi hidrogen 0,699 liter per jam.

4. Sistem ini berkelanjutan selama 10 tahun operasi.

5. Listrik PLN stabil untuk 10 tahun kedepan dengan harga Rp1445/kWh.

6. Kebutuhan hidrogen dalam menghasilkan 1000Wh listrik adalah 0,699 liter, sehingga dalam setahun menghasilkan listrik dengan perhitungan sebagai berikut:

Listrik yang dihasilkan $=\frac{10,98 \text { liter } \times 8760 \mathrm{jam}}{0,699}$

$$
=137.603,43 \mathrm{kWh}
$$

Sehingga menghasilkan nilai jual dalam 1 tahun sebesar :

Pendapatan

$$
\begin{aligned}
& =\operatorname{Rp} 1445 \times 137603,43 \mathrm{kWh} \\
& =\operatorname{Rp} 198836956 / \text { tahun} / 1 \text { bioreaktor }
\end{aligned}
$$

7. Beritkut merupakan tabel perhitungan biaya pengeluaran modal/Capital 
Expenditure (CAPEX) dapat dilihat pada tabel 1.

Tabel 1. Capital Expenditure (CAPEX) (Sumber: Penulis)

\begin{tabular}{clrcr}
\hline No & \multicolumn{1}{c}{ Alat } & Harga (Rp) & Satuan & \multicolumn{1}{c}{ Jumlah (Rp) } \\
\hline 1 & Tabung Gas 1000L & 11.000 .000 & 1 & 11.000 .000 \\
2 & Kompressor & 200.000 & 5 & 1.000 .000 \\
3 & Pipa Gas 1m & 140.000 & 1 & 140.000 \\
4 & Bioreactor 20 L & 24.166 .600 & 1 & 24.166 .600 \\
5 & Tabung Filter CO2 & 1.785 .000 & 1 & 1.785 .000 \\
6 & Fuel Cell 10 MW & 61.085 .000 & 1 & 62.085 .000 \\
7 & Bioreactor 10L & 14.000 .000 & 1 & 14.000 .000 \\
8 & Pompa & 500.000 & 2 & 1.000 .000 \\
\hline \multicolumn{3}{r}{ TOTAL } \\
\hline
\end{tabular}

8. Biaya operasional / Operating Expenditure (OPEX) dapat dilihat pada tabel 2

Tabel 2. Operating Expenditure (OPEX) (Sumber: Penulis)

\begin{tabular}{clrcr}
\hline No & \multicolumn{1}{c}{ Alat } & \multicolumn{1}{c}{ Harga } & Satuan & \multicolumn{1}{c}{ Jumlah } \\
\hline 1 & Limbah POME & 64.200 .000 & 1 & 64.200 .000 \\
2 & Naoh 10 L & 2.500 .000 & 1 & 2.500 .000 \\
\multirow{2}{*}{3} & $\begin{array}{l}\text { Clostridium } \\
\text { Thermocellum }\end{array}$ & 750.000 & $5 \mathrm{Kg}$ & 3.750 .000 \\
& Methanobacterium & 750.000 & $5 \mathrm{Kg}$ & 3.750 .000 \\
4 & Sp & 750.000 & $5 \mathrm{Kg}$ & 3.750 .000 \\
5 & Sytrophomonas Sp & 750.000 & $2.5 \mathrm{Kg}$ & 1.875 .000 \\
6 & Thioalkalivibrio & 750.000 & $2.5 \mathrm{Kg}$ & 1.875 .000 \\
7 & Thioalkalimicrobium & 14.500 .000 & 1 & 14.500 .000 \\
8 & Biaya Perawatan & & 96.200 .000
\end{tabular}

9. Setelah didapatkan CAPEX dan OPEX dapat dihitung Break Even Point (BEP), dapat dilihat perhitungan :

$\mathrm{BEP}=\frac{\text { Pendapatan }}{\text { CAPE } X+O P E X}$

$\mathrm{BEP}=\frac{198.836 .335}{210.376 .600}=1,058$ Tahun

Jadi, BEP yang diperoleh alat Antasena Biohidrogen agar modal kembali adalah dalam waktu 1 tahun 26 hari.

10. Jadi didapatkan Benefit Cost Ratio (BCR) yang dapat dilihat pada pada tabel 3 . 
Tabel 3. Benefit Cost Ratio (BCR) (Sumber: Penulis)

\begin{tabular}{crrr}
\hline \multicolumn{4}{c}{ Perhitungan B/C Ratio } \\
\hline Tahun & Benefit $(\mathrm{Rp})$ & Cost $(\mathrm{Rp})$ & \multicolumn{1}{c}{ B/C Ratio } \\
\hline 1 & 198.836 .335 & 210.376 .600 & 0,945144731 \\
2 & 198.836 .335 & 96.200 .000 & 2,066905769 \\
3 & 198.836 .335 & 96.200 .000 & 2,066905769 \\
4 & 198.836 .335 & 96.200 .000 & 2,066905769 \\
5 & 198.836 .335 & 96.200 .000 & 2,066905769 \\
6 & 198.836 .335 & 96.200 .000 & 2,066905769 \\
7 & 198.836 .335 & 96.200 .000 & 2,066905769 \\
8 & 198.836 .335 & 96.200 .000 & 2,066905769 \\
9 & 198.836 .335 & 96.200 .000 & 2,066905769 \\
10 & 198.836 .335 & 96.200 .000 & 2,066905769 \\
11 & 198.836 .335 & 96.200 .000 & 2,066905769 \\
\hline \multicolumn{4}{c}{1,964927493} \\
\hline
\end{tabular}

Dari tabel di atas, didapatkan BCR 1,9 yang artinya Antasena Biohidrogen layak untuk menjadi inventasi untuk pembangkit listrik renewable energy.

11. Perbandingan harga listrik Antasena Biohidrogen dengan listrik PLN dapat dilihat pada gambar 7 .

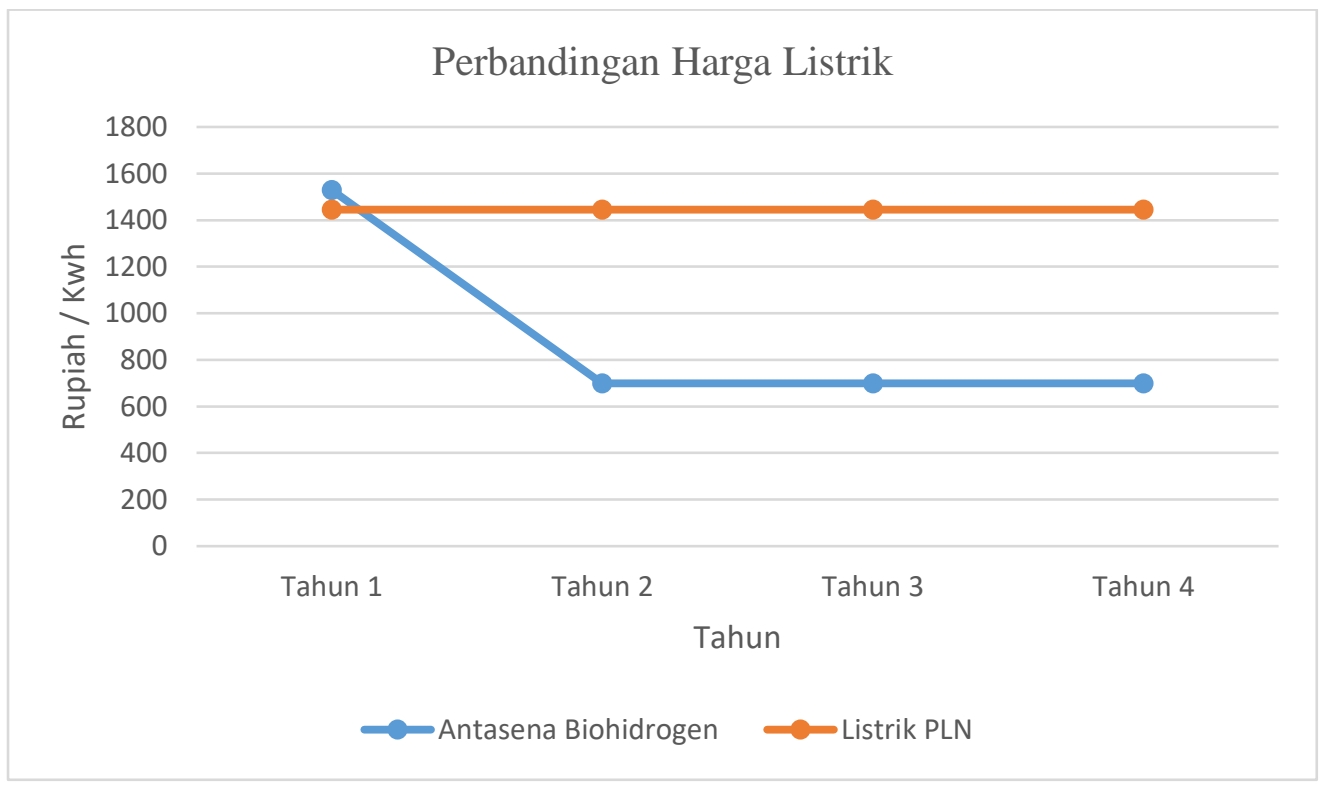

Gambar 8. Perbandingan Harga Listrik dengan PLN

Dapat disimpulkan dari tabel pada tahun pertama Antasena Biohidrogen lebih mahal sebesar Rp 1529/KWh, namun untuk tahun seterusnya listrik Antasena Biohidrogen lebih murah hanya sebesar Rp 699,112/KWh.

\section{Peran Antasena Biohidrogen sebagai Upaya Realisasi SDGs 2030}

Adapun peran Antasena Biohidrogen sebagai upaya kontribusi terhadap Sustainable 


\section{Development Goals (SDGs) 2030 sebagai berikut :}

\section{Goal 7: Energi Bersih dan Terjangkau}

Tujuan-tujuan ini mencakup pencapaian akses ke energi terbarukan, untuk memperluas penggunaan energi ramah lingkungan. Dengan melaksanakan pemajuan ini, dapat menjunjung tinggi peraturan pemerintah dalam PP. 79 tahun 2014 tentang penurunan penggunaan energi fosil yang mencapai 23\% tenaga listrik yang ramah lingkungan pada tahun 2025 [22], serta upaya optimalisasi penggunaan energi terbarukan sebesar $29 \%$ di tahun 2050 .

\section{Goal 9: Infrastruktur, Industri, dan Inovasi}

Infrastruktur adalah usaha yang secara tidak langsung bermanfaat, namun berfungsi sebagai media untuk mempercepat kemajuan [22]. Adapun inovasi hijau berupa alat Antasena Biohdrogen dapat memenuhi tujuan, termasuk membangun kualitas dan infrastruktur, serta mengupayakan inovasi ramah lingkungan yang mengurangi emisi carbon [22].

\section{Goal 13: Penanganan Perubahan Iklim}

Bioreaktor penghasil Antasena Biohidrogen ini mampu menjadi solusi untuk mengurangi perubahan iklim, hidrogen mulai diaplikasikan untuk energi pada kendaraan yang ramah lingkungan dan tanpa emisi karbon, sehingga dapat meningkatkan kemajuan dan investasi menuju masa depan rendah karbon, kemananan iklam, dan berkelanjutan [22].

\section{Pihak yang Dapat Mengimplementasikan Gagasan}

Pihak yang dapat mengimplementasikan Antasena Biohidrogen adalah:

a. PLN: Perlu adanya riset yang mendalam tentang penggunakan gas hidrogen sebagai pembangkit listrik, oleh sebab itu PLN perlu menggandeng pihak akademisi atau peneliti.

b. PT Samator Gas: Perlu adanya riset yang mendalam tentang green energy gas biohidrogen, oleh sebab itu PT Samator Gas perlu menggandeng pihak akademisi atau peneliti.

c. Indsustri Otomotif: Perlu adanya riset tentang kendaraan listrik menggunakan Fuel Cell Electric Vehicle (FECV) dengan berbahan bakar hidrogen.

d. Industri Kelapa Sawit: Pensuplai POME sebagai bahan mentah yang akan diolah menjadi biohidrogen sekaligus menambah pendapatan untuk negara.

e. Pemerintah: Pemerintah berfungsi sebagai pengontrol kebijakan dan sekaligus mensukseskan tentang zero emission pada kendaraan serta pembangkit listrik.

f. Konsultan: Berfungsi untuk menganalisis kelayakan sistem pembangkit ini. Masyarakat: Merupakan pihak yang paling berpengaruh, karena tanpa adanya dukungan dan peran dari masyarakat untuk menjaga atau merawat sistem. pembangkit ini maka akan cepat mengalami kerusakan.

\section{KESIMPULAN}

Berdasarkan permasalahan dan tujuan riset ini, didapatlah kesimpulan untuk menjawab perumusan masalah pada karya tulis kami, yaitu sebagai berikut:

1. Limbah Palm Oil Mill Effluent (POME) dapat dikonversi menjadi energi terbarukan berupa biohidrogen dengan kemurnian $99 \%$ melalui alat bioreaktor yang memanfaatkan bakteri dan filtrasi dalam operasinya, dan memiliki nilai ekonomi sebesar Rp 198836956/tahun untuk satu komponen bioreaktor.

2. Alat bioreaktor penghasil biohidrogen telah didesain secara kompleks, serta telah 
dilakukan simulasi yang menunjukkan hasil safety factor sebesar 2,4 sehingga aman digunakan untuk masyarakat dan industri, khususnya FAW Group Coorporation yang berambisi menciptakan mobilitas masyarakat berbasis hidrogen di China dengan alternatif pegembangan Fuel Cell Electric Vehicle (FCEV).

3. Antasena Biohidrogen mampu memproduksi hidrogen sebagai energi terbarukan yang diaplikasikan pada pembangkit listrik, electric vehicle, dan lain sebagainya, tanpa emisi gas buang. Sehingga memiliki peran penting dalam pembangunan berkelanjutan, khususnya pada poin 7 (Energi Bersih dan Terjangkau), 9 (Infrastruktur, Industri, dan Inovasi), dan poin 13 (Penanganan Perubahan Iklim).

\section{SARAN}

Potensi energi terbarukan di Indonesia sangat besar, tersebar dalam berbagai bentuk energi, serta produk buangan (limbah) yang tidak digunakan lagi. Disamping itu, Indonesia merupakan penghasil kelapa sawit terbesar di dunia yang belum memiliki alternatif pengolahan limbah Palm Oil Mill Effluent (POME). Maka, sudah sepatutnya generasi muda sebagai agent of change mampu mengolah dan memanfaatkan potensi tersebut untuk mengoptimalisasi pengembangan energi terbarukan, sehingga Indonesia dapat mencapai pembangunan berkelanjutan pada tahun 2030 .

\section{DAFTAR PUSTAKA}

[1] Tim Sekretaris Jenderal Dewan Energi Nasional, "Indonesia Energy Out Look 2019," J. Chem. Inf. Model., vol. 53, no. 9, pp. 1689-1699, 2019.

[2] Tempo.com, "Indonesia Merupakan Negara Penghasil Minyak Kelapa Sawit Terbanyak," 2018.

[3] Z. Zainudin and A. Rofik, "Pemanfaatan Limbah Cair Pabrik Kelapa Sawit Sebagai Bioaktivator Untuk Pengomposan Tandan Kosong Kelapa Sawit," Agrifarm J. Ilmu Pertan., vol. 8, no. 1, p. 7, 2019, doi: 10.24903/ajip.v8i1.525.

[4] CNN Indonesia, "Toyota Gaet China Garap Fuel Cell untuk Kendaraan Komersial," $2020 . \quad$ https://www.cnnindonesia.com/teknologi/20200611182253-384512382/toyota-gaet-china-garap-fuel-cell-untuk-kendaraan-komersial.

[5] D. Erivianto, B. A. P, and D. Notosudjono, "Penggunaan Limbah Padat Kelapa Sawit Untuk Menghasilkan Tenaga Listrik Pada Existing Boiler," Sainstech J. Penelit. dan Pengkaj. Sains dan Teknol., vol. 26, no. 2, pp. 85-93, 2020, doi: 10.37277/stch.v26i2.514.

[6] L. Singh, Z. A. Wahid, M. F. Siddiqui, A. Ahmad, M. H. A. Rahim, and M. Sakinah, "Biohydrogen production from palm oil mill effluent using immobilized Clostridium butyricum EB6 in polyethylene glycol," Process Biochem., vol. 48, no. 2, pp. 294298, 2013, doi: 10.1016/j.procbio.2012.12.007.

[7] B. S. Zainal, M. Danaee, N. S. Mohd, and S. Ibrahim, "Effects of temperature and dark fermentation effluent on biomethane production in a two-stage up-flow anaerobic sludge fixed-film (UASFF) bioreactor," Fuel, vol. 263, no. January, 2020, doi: 10.1016/j.fuel.2019.116729.

[8] T. P. Vo, C. H. Lay, and C. Y. Lin, "Effects of hydraulic retention time on biohythane production via single-stage anaerobic fermentation in a twocompartment bioreactor," Bioresour. Technol., vol. 292, no. June, p. 121869, 2019, doi: 10.1016/j.biortech.2019.121869.

[9] A. Ahmad et al., "Produksi Biohidrogen dari POME ( Palm Oil Mill Effluent ) Menggunakan Bioreaktor Hibrid Anaerob dengan Variasi Waktu Retensi Hidrolik," pp. 14-15, 2020.

[10] K. Rambabu, P. L. Show, G. Bharath, F. Banat, M. Naushad, and J. S. Chang, 
"Enhanced biohydrogen production from date seeds by Clostridium thermocellum ATCC 27405," Int. J. Hydrogen Energy, vol. 45, no. 42, pp. 22271-22280, 2020, doi: 10.1016/j.ijhydene.2019.06.133.

[11] L. Zheng et al., "Study on explosion characteristics of premixed hydrogen/biogas/air mixture in a duct," Int. J. Hydrogen Energy, vol. 44, no. 49, pp. 27159-27173, 2019, doi: 10.1016/j.ijhydene.2019.08.156.

[12] A. Syauqi, I. R. Kusumawardhany, and L. U. Widodo, "Produksi Gas Hidrogen Dari Biomassa Dengan Proses Anaerob," J. Tek. Kim., vol. 13, no. 1, pp. 17-21, 2018, doi: 10.33005/tekkim.v13i1.1147.

[13] Sulistyo and Darjat, "Kajian Fuel Cell ( Sel Bahan Bakar ) dari Tinjauan Material dan Daya Keluaran," Proceeding Semin. Nas. Tah. Tek. Mesin XV (SNTTM XV), no. Snttm Xv, pp. 5-6, 2016.

[14] I. A. Safitri, B. Rudiyanto, A. Nursalim, and B. Hariono, "Uji Kinerja Smart Gried Fuel Cell Tipe Proton Exchange Membran (PEM) Dengan Penmbahan Hidrogen," J. Ilm. Inov., vol. 16, no. 1, 2016, doi: 10.25047/jii.v16i1.2.

[15] Kumparan.com, "Indonesia Siap Genjot Ekspor Minyak Sawit ke China," $15 \mathrm{Mei}$ 2017, 2017. https://kumparan.com/kumparannews/indonesia-siap-genjot-eksporminyak-sawit-ke-china.

[16] ESDM, "Keputusan Menteri Energi Sumber Daya dan Mineral Nomer 77 Tahun 2019.pdf," $06 \quad$ May $2019,2019$. https://jdih.esdm.go.id/index.php/web/result/1956/detail (accessed Sep. 28, 2020).

[17] Direktorat Konservasi Energi Kementerian ESDM, "Data \& Informasi - Konservasi Energi 2018," p. 61, 2019, [Online]. Available: www.ebtke.esdm.go.id.

[18] A. Palilu, "Analisis Pengaruh Pembangunan Infrastruktur Transportasi Terhadap Produk Domestik Regional Bruto Kota Ambon," Bul. Stud. Ekon., vol. 23, no. 2, p. 227, 2019, doi: 10.24843/bse.2018.v23.i02.p06.

[19] Bambang Trisakti, Irvan, Hari Tiarasti, and Irma Suraya, "Perancangan Awal Pabrik Biohidrogen Dari Limbah Cair Pabrik Kelapa Sawit Dengan Fermentasi Anaerobik Pada Kondisi Termofilik," J. Tek. Kim. USU, vol. 1, no. 1, pp. 30-37, 2012, doi: $10.32734 /$ jtk.v1i1.1403.

[20] T. Siregar, "Penggunaan Zeolit Alam Sentani Sebagai," vol. 10, no. September 2013, pp. 22-31, 2014.

[21] S. Suhartati, P. Tri, and D. Supriningsih, "Pemanfaatan Limbah Asbes Sebagai Prekursor Zeolit dalam Proses Adsorpsi CO 2," vol. 02, no. 01, pp. 28-33, 2019, doi: 10.20885/ijca.vol2.iss1.art4.

[22] United Nations, "The Sustainable Development Goals in Indonesia," 2021. https://indonesia.un.org/en/sdgs. 